\title{
Antioxidant activity of extract from Polygonum aviculare L.
}

\author{
CHIN-YUAN HSU
}

Department of Life Science, Chang Gung University, Tao-Yuan, Taiwan

\begin{abstract}
Free radicals induce numerous diseases by lipid peroxidation, protein peroxidation, and DNA damage. It has been reported that numerous plant extracts have antioxidant activities to scavenge free radicals. Whether Polygonum aviculare L. (Polygonaceae) has antioxidant activity is unknown. In this study, dried Polygonum aviculare L. was extracted by ethanol, and the extract was lyophilized. The antioxidant activities of extract powder were examined by free radical scavenging assays, superoxide radical scavenging assays, lipid peroxidation assays and hydroxyl radical-induced DNA strand scission assays. The results show that the IC50 value of Polygonum aviculare L. extract is $50 \mu \mathrm{g} / \mathrm{ml}$ in free radical scavenging assays, $0.8 \mu \mathrm{g} / \mathrm{ml}$ in superoxide radical scavenging assays, and $15 \mu \mathrm{g} / \mathrm{ml}$ in lipid peroxidation assays, respectively. Furthermore, Polygonum aviculare L. extract has DNA protective effect in hydroxyl radical-induced DNA strand scission assays. The total phenolics and flavonoid content of extract is $677.4 \pm 62.7 \mathrm{mg} / \mathrm{g}$ and $112.7 \pm 13 \mathrm{mg} / \mathrm{g}$. The results indicate that Polygonum aviculare L. extract clearly has antioxidant effects.
\end{abstract}

Key terms: antioxidant activity, free radical, phenolics, lipid peroxidation, DNA damage Polygonum aviculare L.

\section{INTRODUCTION}

Reactive oxygen species produced by ultraviolet light, ionizing radiation, chemical reactions, and metabolic processes have numerous pathological effects, such as causing lipid peroxidation, protein peroxidation, DNA damage, and cellular degeneration related to cardiovascular disease, ageing, cancer, inflammatory diseases, and a variety of other disorders (2, $6,9,16,20,28)$. They include superoxide radical anion $\left({ }^{\circ} \mathrm{O}_{2-}\right)$, hydroxyl radicals $\left({ }^{\circ} \mathrm{OH}\right)$, singlet oxygen $\left({ }^{1} \mathrm{O}_{2}\right)$, and hydrogen peroxide $\left(\mathrm{H}_{2} \mathrm{O}_{2}\right)$. In cellular oxidation reactions, superoxide radical normally is formed first, and its effects can be magnified because it produces other kinds of cell-damaging free radicals and oxidizing agents. The damaging action of the hydroxyl radical is the strongest among free radicals (18).

Phenolics have been reported to have a capacity to scavenge free radicals. They are commonly found in both edible and nonedible plants and have multiple biological effects, including antioxidant activity (13, 27 ). The antioxidant activity of phenolics is mainly due to their redox properties, which allow them to act as reducing agents, hydrogen donators, and singlet oxygen quenchers. In addition, they have a metal chelation potential (22). Phenolics, such as flavonoids, phenolic acids, stilbenes, lignans, lignin, and tannins, are especially common in leaves, flowering tissues, and woody parts, such as stems and barks (17). They have been suggested to play a preventive role in the development of cancer, heart disease, and ageing-related diseases.

The importance of the antioxidant constituents of plant materials in the maintenance of health and protection from ageing-related diseases has intrigued scientist for a long time. I have screened the 
antioxidant activity of a variety of wild plants and other substances used in traditional Oriental medicine by 1,1Diphenyl-2-picrylhydrazyl (DPPH) free radical scavenging assays. The results show that Polygonum aviculare L. (Polygonaceae) exhibits a DPPH free radical scavenging effect. Polygonum aviculare L. is used in traditional Oriental medicine and belongs to the "li-shui-shen-shih" category of drugs. It is used traditionally to treat ailments caused by high humidity, because of its diuretic property. In the present study, I wish to study the antioxidant effects of Polygonum aviculare L. on superoxide radical scavenging, lipid peroxidation, and DNA damage.

\section{METHODS}

\section{Chemicals}

1,1-Diphenyl-2-picrylhydrazyl (DPPH), nitroblue tetrazolium chloride (NBT), 2thiobarbituric acid (TBA), $\Phi$ X174 RF1 supercoiled DNA, Folin-Ciocalteu reagent, L-ascorbic acid, and (+)-catechin were purchased from Sigma Chemical Co. The other chemicals and solvents used in this experiment were of the highest quality available. Dried Polygonum avicular was purchased from a local drugstore.

\section{Preparation of plant extract}

Dried Polygonum aviculare L. was made into powder form. $5 \mathrm{~g}$ of dried powder were extracted in $50 \mathrm{ml} 50 \%$ ethanol solution at $25^{\circ} \mathrm{C}$ for 30 min with shaking. The extract was centrifuged at $15000 \mathrm{rpm}$ for $3 \mathrm{~min}$, and the supernatant was collected. The supernatant was concentrated in a rotary evaporator and then lyophilized. The resulting powder extract was used in this study (4).

\section{DPPH assay}

$1 \mathrm{mg}$ extract powder was dissolved in $1 \mathrm{ml}$ of $50 \%$ ethanol solution to obtain $1000 \mu \mathrm{g} /$ $\mathrm{ml}$ sample solution. $1000 \mu \mathrm{g} / \mathrm{ml}$ solutions were series diluted into $1 \mu \mathrm{g} / \mathrm{ml}, 5 \mu \mathrm{g} / \mathrm{ml}, 10$ $\mu \mathrm{g} / \mathrm{ml}, 20 \mu \mathrm{g} / \mathrm{ml}, 50 \mu \mathrm{g} / \mathrm{ml}, 100 \mu \mathrm{g} / \mathrm{ml}, 200$ $\mu \mathrm{g} / \mathrm{ml}, 500 \mu \mathrm{g} / \mathrm{ml}$, and $1000 \mu \mathrm{g} / \mathrm{ml}$ with $50 \%$ ethanol. In each reaction, the solutions were mixed with $1 \mathrm{ml}$ of $0.1 \mathrm{mM} 1,1$-Diphenyl-2picrylhydrazyl (DPPH), $0.45 \mathrm{ml}$ of $50 \mathrm{mM}$ Tris-HCl buffer ( $\mathrm{pH} 7.4$ ), and $0.05 \mathrm{ml}$ samples at room temperature for $30 \mathrm{~min}$. $50 \%$ ethanol solution was used as control. The reduction of the DPPH free radical was measured by reading the absorbance at 517 nm. DPPH, a purple-colored, stable free radical is reduced to the yellow-colored diphenylpicrylhydrazine when antioxidants are added. L-ascorbic acid and (+)-catechin were used as positive controls. The inhibition ratio (percent) was calculated from the following equation: $\%$ inhibition $=$ [(absorbance of control - absorbance of test sample)/absorbance of control] x $100 \%$. The antioxidant activity of each sample was expressed in terms of IC50 (micromolar concentration required to inhibit DPPH radical formation by $50 \%$ ), calculated from the inhibition curve $(5,8,30)$.

\section{NBT (superoxide scavenging) assay}

The superoxide anion radical scavenging activity was performed by using the methods of Liu and $\mathrm{Ng}$ (18). Superoxide radicals were generated in $3.0 \mathrm{ml}$ of Tris$\mathrm{HCl}$ buffer (16 mM, pH 8.0), which contained $78 \mu \mathrm{M} \beta$-nicotinamide adenine dinucleotide (reduced form, NADH), 50 $\mu \mathrm{M}$ nitroblue tetrazolium (NBT), $10 \mu \mathrm{M}$ phenazin methosulfate (PMS), and test samples in $50 \%$ ethanol solution (final concentrations were $1,5,10,20,50$, and $100 \mu \mathrm{g} / \mathrm{ml}$, respectively). The color reaction of superoxide radicals and NBT was detected at OD $560 \mathrm{~nm}$. (+)-catechin was used as a positive control. The inhibition ratio (\%) was calculated from the following equation: $\%$ inhibition $=[($ absorbance of control - absorbance of test sample)/ absorbance of control] x $100 \%$.

\section{Lipid peroxidation assay}

The brain of young adult male Balb/c mice were dissected and homogenized with a homogenizer in ice-cold Tris- $\mathrm{HCl}$ buffer $(20$ $\mathrm{mM}, \mathrm{pH} 7.4$ ) to produce a $1 / 10$ homogenate. 
The homogenate was centrifuged at $12000 \mathrm{~g}$ for $15 \mathrm{~min}$ at $4{ }^{\circ} \mathrm{C}$, and the supernatant was used for in vitro lipid peroxidation assay. A $1 \mathrm{ml}$ aliquot of liposome was incubated with the test samples (final concentrations were 1 , $5,10,20,50$, and $100 \mu \mathrm{g} / \mathrm{ml}$, respectively) in the presence of $10 \mathrm{mM} \mathrm{FeSO}_{4}$ and $0.1 \mathrm{mM}$ ascorbic acid at $37^{\circ} \mathrm{C}$ for $1 \mathrm{~h}$. The reaction was terminated by the addition of $1.0 \mathrm{ml}$ of trichloroacetic acid (TCA; 28\%, w/v) and $1.5 \mathrm{ml}$ of TBA $(1 \%, \mathrm{w} / \mathrm{v})$, followed by heating at $100^{\circ} \mathrm{C}$ for $15 \mathrm{~min}$. The absorbance of the malondialdehyde (MDA)-TBA complex was measured at $532 \mathrm{~nm}$. (+)catechin was used as a positive control. The inhibition ratio (\%) was calculated from the following equation: $\%$ inhibition = [(absorbance of control - absorbance of test sample)/absorbance of control] x $100 \%$ (4).

\section{DNA strand scission assay}

The assay was performed according to the method of Keum et al., with minor modifications (15). The reaction mixture $(30 \mu \mathrm{l})$ contained $10 \mathrm{mM}$ Tris- $\mathrm{HCl}, 1 \mathrm{mM}$ EDTA buffer (pH 8.0), $\Phi$ X174 RF1 supercoiled DNA $(0.6 \mu \mathrm{g})$, and $\mathrm{H}_{2} \mathrm{O}_{2}$ $(0.04 \mathrm{M})$. Various amounts of the test extract samples dissolved in $10 \mu \mathrm{l}$ of ethanol (final concentrations of the plant extract in each assay were $1,10,100,500$, and $1000 \mu \mathrm{g} / \mathrm{ml}$, respectively) were added prior to $\mathrm{H}_{2} \mathrm{O}_{2}$ addition. Hydroxyl radicals were generated by irradiation of the reaction mixtures at a distance of $5 \mathrm{~cm}$ with a $12 \mathrm{~W}$ UV lamp. After incubation at room temperature for $20 \mathrm{~min}$, the reaction was terminated by the addition of a loading buffer $(0.25 \%$ bromophenol blue tracking dye and $40 \%$ sucrose), and the mixtures were then analyzed by $0.8 \%$ submarine agarose gel electrophoresis $(50 \mathrm{eV}, 1.5 \mathrm{~h})$. The gel was stained with ethidium bromide, destained in water, and photographed on a transilluminator (4).

\section{Determination of total flavonoid}

$1 \mathrm{mg}$ samples were added in $1 \mathrm{ml}$ of $80 \%$ ethanol. A aliquot of $0.5 \mathrm{ml}$ was added to test tubes containing $0.1 \mathrm{ml}$ of $10 \%$ aluminum nitrate, $0.1 \mathrm{ml}$ of $1 \mathrm{M}$ potassium acetate, and $4.3 \mathrm{ml}$ of $80 \%$ ethanol. The absorbance of the supernatant was measured at $415 \mathrm{~nm}$ after $40 \mathrm{~min}$ at room temperature. Total flavonoid concentration was calculated using quercetin as standard (19).

\section{Determination of Total Phenolics}

Total phenolics content was determined according to the Folin-Ciocalteu method (23), using gallic acid as a standards $1 \mathrm{mg}$ extract powders were dissolved in $1 \mathrm{ml} \mathrm{50 \%}$ methanol solution. $0.5 \mathrm{ml}$ extract solution was mixed with $0.5 \mathrm{ml}$ of $50 \%$ FolinCiocalteu reagent. The mixture was let sit for 2-5 min before the addition of $1.0 \mathrm{ml}$ of $20 \% \mathrm{Na}_{2} \mathrm{CO}_{3}$. The mixture was centrifuged at $150 \mathrm{~g}$ for $8 \mathrm{~min}$ after $10 \mathrm{~min}$ of incubation at room temperature. The absorbance of the supernatant was measured at $730 \mathrm{~nm}$. The total phenolic content was expressed as gallic acid equivalents (GAE) in milligrams per gram sample (4).

\section{RESULTS}

The free radical scavenging activity of Polygonum aviculare L. extract was assessed by 1,1-Diphenyl-2-picrylhydrazyl (DPPH) assay. (+)-catechin and L-ascorbic acid were used as controls. Both are wellknown antioxidant compounds. The result is shown in Figure 1. The $\mathrm{IC}_{50}$ values (the concentration required to inhibit radical formation by 50\%) of Polygonum aviculare L. extract are $50 \mu \mathrm{g} / \mathrm{ml}$. The $\mathrm{IC}_{50}$ values of (+)catechin and ascorbic acid are $35 \mu \mathrm{g} / \mathrm{ml}$ and $50 \mu \mathrm{g} / \mathrm{ml}$, respectively; they exhibit a similar curve of antioxidant activity compared to (+)-catechin and L-ascorbic acid. The $\mathrm{IC}_{50}$ value of Polygonum aviculare $\mathrm{L}$. extract is lower than that of (+)-catechin and is similar to that of Lascorbic acid. This result demonstrates that Polygonum aviculare L. extract has an inhibitory effect on the DPPH radical.

The superoxide scavenging activity of Polygonum aviculare L. extract was evaluated by NBT (Superoxide Scavenging) assay. (+)-catechin served as a control. The result is shown in Figure 2. The $\mathrm{IC}_{50}$ value of Polygonum aviculare L. extract is $0.8 \mu \mathrm{g} /$ 
$\mathrm{ml}$. The $\mathrm{IC}_{50}$ value of (+)-catechin is $40 \mu \mathrm{g} /$ $\mathrm{ml}$. Almost all superoxide radicals were inhibited by $10 \mu \mathrm{g} / \mathrm{ml}$ Polygonum aviculare L. extract. The superoxide scavenging activity of Polygonum aviculare L. extract is apparently higher than that of (+)-catechin. Therefore, Polygonum aviculare L. seems to be a potential source of superoxide radicals scavenging. This result shows that Polygonum aviculare L. extract has a significant superoxide scavenging activity.

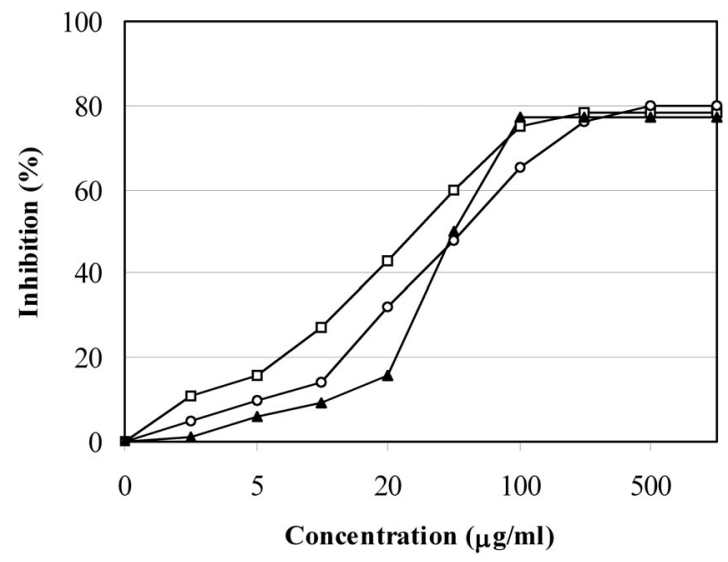

Figure 1: Free-radical scavenging activity of Polygonum aviculare L. extract are measured by using the DPPH assay: $(\diamond)(+)$ catechin; (O) ascorbic acid; ( $\Delta)$ Polygonum aviculare L. extract. Results are mean $\pm \mathrm{SD}(\mathrm{N}=5)$.

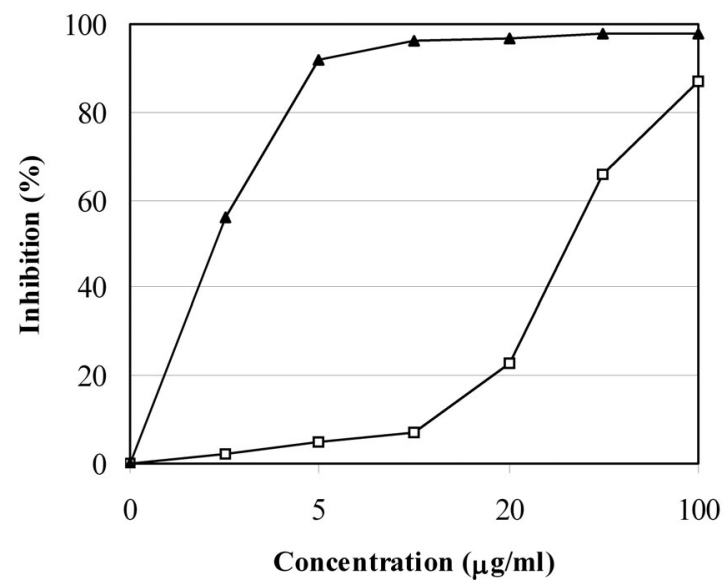

Figure 2: Superoxide scavenging activity of Polygonum aviculare L. extract are measured by using the NBT assay: $(\diamond)(+)$ catechin; ( $(\mathbf{\Delta})$ Polygonum aviculare L. extract. Results are mean $\pm \mathrm{SD}(\mathrm{N}=5)$.
The lipid peroxidation suppressing activity of Polygonum aviculare L. extract was estimated by TBA assay. (+)-catechin was employed as control. The result is shown in Figure 3 . The $\mathrm{IC}_{50}$ values of Polygonum aviculare L. extract is $16 \mu \mathrm{g} /$ $\mathrm{ml}$. The $\mathrm{IC}_{50}$ value of (+)-catechin is $17 \mu \mathrm{g} /$ ml. Compared to $(+)$-catechin, they exhibit the similar curve of antioxidant activity. The lipid peroxidation suppressing activity of Polygonum aviculare L. extract is identical to that of $(+)$-catechin. This result indicates that Polygonum aviculare L. extract has suppressing activity on lipid peroxidation.

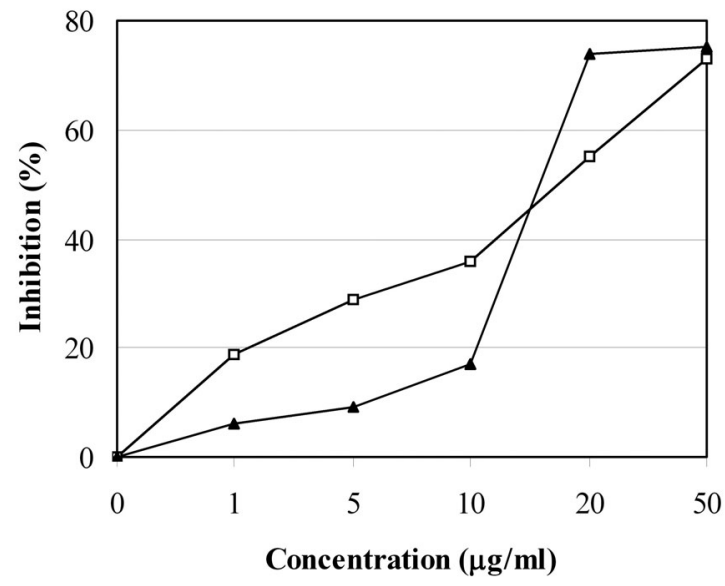

Figure 3: Effects of Polygonum aviculare L. extract on both ferric ion and ascorbic acid induced lipid peroxidation on mouse brain homogenates: $(\diamond) \quad(+)$ catechin;

Polygonum aviculare L. extract. Results are mean $\pm \mathrm{SD}(\mathrm{N}=5)$.

ФX174 RF1 DNA strand scission induced by UV photolysis of $\mathrm{H}_{2} \mathrm{O}_{2}$ elevated the protective effect of DNA of Polygonum aviculare L. extract. The result is shown in Figure 4. $\Phi \times 174$ RF1 supercoiled DNA was utilized as control (lane 1). UV illumination alone did not cause DNA strand cleavage (lane 2). The treatment of supercoiled DNA with UV plus $\mathrm{H}_{2} \mathrm{O}_{2}$ led to the conversion of the DNA to open circular form (lane 3 ). The treatment of supercoiled DNA with UV, $\mathrm{H}_{2} \mathrm{O}_{2}$ plus the different concentration of 
Polygonum aviculare L. extract led to the maintenance of the DNA in the supercoiled form (lanes 4-8). Almost complete protection was expressed at a dose of $1000 \mu \mathrm{g} / \mathrm{ml}$. This protective effect of DNA exhibits dose-dependency. This result shows that Polygonum aviculare L. extract has DNA protective activity under oxidative stress.

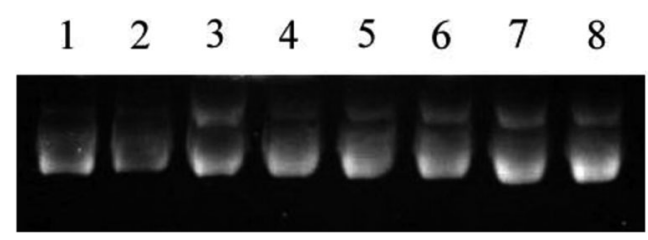

$\mathrm{OC}$ $\mathrm{SC}$

Figure 4: Protection effect of Polygonum aviculare L. extract on DNA strand scission induced by $\mathrm{H}_{2} \mathrm{O}_{2}$ and UV. $\Phi X 174 \mathrm{RF} 1$ supercoiled DNA as control (lane 1), ФX174 RF1 supercoiled DNA was exposed to UV alone (lane 2), UV plus $\mathrm{H}_{2} \mathrm{O}_{2}$ (lane 3), or plus $\mathrm{H}_{2} \mathrm{O}_{2}$ in the presence of final concentration of $1000 \mu \mathrm{g} / \mathrm{ml}$ (lane 4), $500 \mu \mathrm{g} / \mathrm{ml}$ (lane 5), 100 $\mu \mathrm{g} / \mathrm{ml}$ (lane 6), $10 \mu \mathrm{g} / \mathrm{ml}$ (lane 7), $1 \mu \mathrm{g} / \mathrm{ml}$ (lane 8) of Polygonum aviculare L. extract. Lane 1 represents native $\Phi X 174$ RF1 supercoiled DNA without any treatment. OC: Open circular; SC: Super coiled.

Plant phenolics are widely distributed in plants. They are highly effective free radical scavengers and exhibit strong antioxidant activity. The content of total phenolics in the Polygonum aviculare L. was determined spectrometrically according to the Folin-Ciocalteu procedure and calculated as gallic acid equivalent contents. The result is shown in Table 1 . The total phenolic content of Polygonum aviculare L. extract is $677.4 \pm 62.7 \mathrm{mg} / \mathrm{g}$. The content of total flavonoid in the Polygonum aviculare L. also was determined spectrometrically and calculated as quercetin equivalents content. The result is shown in Table 1. The total flavonoid content of Polygonum aviculare L. extract is $112.7 \pm 13 \mathrm{mg} / \mathrm{g}$. These results imply that Polygonum aviculare L. extract contains a high quantity of phenolics and flavonoids.

\section{TABLE 1}

Total phenolic content and total flavonoid content of ethanolic extract from Polygonum aviculare

\begin{tabular}{lcc}
\hline Extract & $\begin{array}{c}\text { Total phenolic } \\
(\mathrm{mg} \text { of GAE/g })\end{array}$ & $\begin{array}{c}\text { Total flavonoid } \\
(\mathrm{mg} / \mathrm{g} \text { of samples })\end{array}$ \\
\hline $\begin{array}{l}\text { Polygonum } \\
\text { aviculare }\end{array}$ & $677.4 \pm 62.7(\mathrm{~N}=8)$ & $112.7 \pm 13(\mathrm{~N}=10)$
\end{tabular}

Total phenolics are expresed as gallic acid equivalent (GAE).

Total flavonoid are expresed as mg of total flavonoid content / $g$ of samples based on quercetin as standard.

Values represent mean \pm S.D.

\section{DISCUSSION}

Antioxidant activity of Polygonum aviculare L. extract has been found by means of free radical scavenging assays, superoxide radical scavenging assays, lipid peroxidation assays, and hydroxyl radicalinduced DNA strand scission assays. In addition, Polygonum aviculare L. extract has high phenolics and flavonoid contents. This study indicates that Polygonum aviculare L. extract obviously has antioxidant effects.

DPPH is a stable radical that has been used widely to evaluate the antioxidant activity of various natural products (12). In this study, DPPH scavenging activity has been found in Polygonum aviculare L. extract. The maximum inhibition of Polygonum aviculare, (+)catechin and ascorbic acid is about $80 \%$ in this study. The maximum inhibition concentration of Polygonum aviculare L. and (+)-catechin is approximately $100 \mu \mathrm{g} / \mathrm{ml}$. The maximum inhibition concentration of ascorbic acid is approximately $200 \mu \mathrm{g} / \mathrm{ml}$. The inhibitory curve of DPPH scavenging activity of Polygonum aviculare L. is similar to that of Acacia confusa (4), Cat's claw (Uncaria tomentosa) (24), and Anthriscus cerefolium (5). However, the $\mathrm{IC}_{50}$ value of Polygonum aviculare $\mathrm{L} .(50 \mu \mathrm{g} / \mathrm{ml})$ is less than that of Acacia confusa (5 $\mu \mathrm{g} / \mathrm{ml})$, Cat's claw (Uncaria tomentosa) (18 $\mu \mathrm{g} / \mathrm{ml})$, and Anthriscus cerefolium $(45 \mu \mathrm{g} / \mathrm{ml})(4,24,5)$. Nevertheless, Polygonum aviculare L. 
extract is a potential source of natural antioxidants.

In cellular oxidation reactions, superoxide radicals normally are formed first, and their effects can be magnified because they produce other kinds of free radicals and oxidizing agents (18). Additionally, xanthine oxidase is one of the main enzymatic sources of those reactive oxygen species in vivo. In this study, superoxide radicals scavenging property has been found in Polygonum aviculare L. extract. The $\mathrm{IC}_{50}$ value of Polygonum aviculare $\mathrm{L}$. extract is $0.8 \mu \mathrm{g} / \mathrm{ml}$, whereas the $\mathrm{IC}_{50}$ value of (+)-catechin is $40 \mu \mathrm{g} / \mathrm{ml}$. The maximum inhibitory effect of Polygonum aviculare L. is about $100 \%$. The maximum inhibition concentration of Polygonum aviculare L. is approximately 10 $\mu \mathrm{g} / \mathrm{ml}$. However, the maximum inhibition concentration of $(+)$-catechin is higher than $100 \mu \mathrm{g} / \mathrm{ml}$. It is noteworthy that the superoxide scavenging activity of Polygonum aviculare L. extract is superior to that of (+)-catechin. Moreover, the $\mathrm{IC}_{50}$ value of Polygonum aviculare L. $(0.8 \mu \mathrm{g} / \mathrm{ml})$ is larger than that of Paeonia suffruticosa (50 $\mu \mathrm{g} / \mathrm{ml})$ (18). In other words, Polygonum aviculare $\mathrm{L}$. has better superoxide radicals scavenging activity than Paeonia suffruticosa. These results show that Polygonum aviculare L. is an important source for superoxide radical scavenging.

In the current study, lipid peroxidation of mouse brain homogenates was induced by ferric ion plus ascorbic acid. Lipid peroxidation scavenging activity has been found in Polygonum aviculare L. extract. The $\mathrm{IC}_{50}$ value of Polygonum aviculare $\mathrm{L}$. extract is about $16 \mu \mathrm{g} / \mathrm{ml}$. The $\mathrm{IC}_{50}$ value of (+)-catechin is about $17 \mu \mathrm{g} / \mathrm{ml}$. The maximum inhibitory effect of Polygonum aviculare L. is about $75 \%$. The maximum inhibition concentration of Polygonum aviculare L. is approximately $20 \mu \mathrm{g} / \mathrm{ml}$. The inhibitory effect of Polygonum aviculare L. is higher than that of $(+)$ catechin when the concentration is higher than $\mathrm{IC}_{50}$ values. In other words, Polygonum aviculare L. extract has better scavenging effect than (+)-catechin when the concentration is higher than $17 \mu \mathrm{g} / \mathrm{ml}$. This result indicates that Polygonum aviculare L. extract is a good source of lipid peroxidation scavenging.

The cellular damage resulting from hydroxyl radicals is strongest among free radicals. Hydroxyl radicals can be generated by biochemical reactions. Superoxide radical is converted by superoxide dismutase to hydrogen peroxide, which subsequently can produce extremely reactive hydroxyl radicals in the presence of transition metal ions, such as iron and copper or by UV photolysis. Hydroxyl radicals can attack DNA to cause strand scission. That is, incubation of $\Phi \times 174$ RF1 supercoiled DNA with $\mathrm{H}_{2} \mathrm{O}_{2}$ and then UV radiation resulted in complete conversion of supercoiled DNA to the open circular form. In this study, the administration of Polygonum aviculare L. extract to the reaction mixture substantially decreased the DNA strand scission induced by both $\mathrm{H}_{2} \mathrm{O}_{2}$ and UV radiation. It shows a dosedependent protection of DNA under oxidative stress. The higher the concentration of Polygonum aviculare L. extracts, the better the DNA protection. There is almost complete protection at a dose of $1000 \mu \mathrm{g} / \mathrm{ml}$. The effect of DNA protection of Polygonum aviculare L. is similar to that of Acacia confusa (4). These results reveal that Polygonum aviculare L. extract is an excellent DNA protector.

Phenolics are found in large quantities in the plant kingdom, and they have been shown to have multiple biological functions, including antioxidant activity $(21,25,14)$. In this study, we examined the content of phenolics from the extract of Polygonum aviculare. The result showed that Polygonum aviculare L. extract contains $677.4 \pm 62.7 \mathrm{mg} / \mathrm{g}$ phenolics. It indicated that the Polygonum aviculare extract contained a higher amount of phenolics than the bark and heartwood extracts of Acacia confusa based on Folin-Ciocalteu procedures (4). Therefore, Polygonum aviculare L. is a significant source of phenolics. The results in this study suggest that the effectiveness of the antioxidant activity of Polygonum aviculare extract is probably related to the high contents of phenolics, and the observed antioxidant activities of the extract may be due to the hydroxyl groups in phenolics (10). 
A similar finding has been demonstrated in the plant extracts of Eucommia ulmoides (Du-zhong) and Acacia confusa in which enriched phenolics correlated well with their antioxidant activities $(4,29)$.

It also has been reported that Polygonum aviculare L. can be employed supportively in the therapy of gingivitis by oral rinse (7). It was suggested that this phenomenon was attributed to the flavonoid components that decrease capillary fragility and exert a cortisone-like effect on gingival tissues (7). In this study, we examined the content of flavonoids from the extract of Polygonum aviculare. The result showed that Polygonum aviculare L. extract contains high flavonoids, $112.7 \pm 13 \mathrm{mg} / \mathrm{g}$. It has been suggested that the therapeutic effect of Polygonum aviculare L. on gingivitis is derived from its high flavonoid. Additionally, the flavonoid content of Polygonum aviculare L. also is higher than that of propolis (29).

It is well known that free radicals are the principal cause of several diseases, including Parkinson's disease, coronary heart disease, cancer, and Alzheimer's disease (3, 1, 11, 26). This study demonstrated that Polygonum aviculare L. has high phenolics contents and excellent antioxidant activity. It would be interesting to investigate further the potential effectiveness of Polygonum aviculare $\mathrm{L}$. for treating diseases caused by the overproduction of free radicals. Also, the antimicrobial effect, bioavailability and potential toxicity of Polygonum aviculare $\mathrm{L}$ need to be studied in vivo.

\section{ACKNOWLEDGEMENTS}

This work was supported by NSC 94-2311B-182-008 grants from the National Science Council, R. O. C.

\section{REFERENCES}

1. ADAMS JD, ODUNZE IN (1991) Oxygen free radicals and Parkinson disease. Free Radical Biol Med 10: 161169

2. BAUEROVA K, BEZEK A (1999) A role of reactive oxygen and nitrogen species in pathogenesis of rheumatoid disease. Gen Physiol Biophys 18: 15-20
3. CERUTTI PA (1994) Oxy-radicals and Cancer. Lancet 344: 862-863

4. CHANG S-T, WU J-H, WANG S-Y, KANG P-L, YANG N-S, SHYUR L-F (2001) Antioxidant activity of extracts from Acacia confuse bark and heartwood. J Agric Food Chem 49: 3420-3424

5. FEJES S, BLÁZOVICS A, LUGASI A, LEMBERKOVICS E, PETRI G, KÉRY A (2000) In vitro antioxidant activity of Anthriscus cerefolium L. (Hoffm.) extracts. J Ethnopharmacol 69: 259-265

6. FINKEL T, HOLBROOK NJ (2000) Oxidants, oxidative stress and biology of ageing. Nature 408: 239-2479

7. GONZÁLEZ BEGNE M, YSLAS N, REYES E, OUIROZ V, SANTANA J, JIMÉNEZ G (2001) Clinical effect of a Mexican Sanguinaria extract (Polygonum aviculare L.) on gingivitis. J Ethnopharmacol 74: 45-51

8. GYAMFI MA, YONAMINE M, ANIYA Y (1999) Freeradical scavenging action of medicinal herbs from Ghana Thonningia sanguinea on experimentallyinduced liver injuries. Gen Pharmacol 32: 661-667

9. HALLIWELL B, GUTTERIDGE JMC, CROSS CE (1992) Free-radicals, antioxidants and human diseases: Where are we now? J Lab Clin Med 119: 598-620

10. HATANO T, EDAMATSU R, HIRAMATSU M, MORI A, FUJITA Y, YASUHARA T, YOSHIDA T, OKUDA $\mathrm{T}$ (1989) Effects of interaction of tannins with coexisting substances. VI. Effects of tannins and related polyphenols on superoxide anion radical and on DPPH radical. Chem Pharm Bull 37: 2016-202

11. HERTOG MGL, FESKENS EJM, HOLLMAN PCH, KATAN MB, KROMHOUT D (1993) Dietary antioxidant flavonoids and risk of coronary heart disease: The Zutphen elderly study. Lancet 342: $1007-$ 1011

12. HU C, KITTS DD (2000) Studies on the antioxidant activity of Echinacea root extract. J Agric Food Chem 48: $1466-1472$

13. KÄHKÖNEN MP, HOPIA AI, VUORELA HJ, RAUUHA JP, PIHLAJA K, KUJALA TS, HEINONEN M (1999) Antioxidant activity of plant extracts containing phenolic compounds. J Agric Food Chem 47: 3954-3962

14. KAPLAN M, AVIRAM M (2004) Red wine administration to apolipoprotein E-deficient mice reduces their macrophage-derived extracellular matrix atherogenic properties. Biol Res 37: 239-245

15. KEUM YS, PARK KK, LEE JM, CHUN KS, PARK JH, LEE SK, KWON H, SURH YJ (2000) Antioxidant and anti-tumor promoting activities of the methanol extract of heat-processed ginseng. Cancer Lett 150: 4148

16. KNIGHT JA (1995) Diseases related to oxygen-derived free radicals. Ann Clin Lab Sci 25: 111-121

17. LARSON RA (1988) The antioxidants of higher plants. Phytochemistry 27: 969-978

18. LIU F, NG TB (2000) Antioxidative and free radical scavenging activities of selected medicinal herbs. Life Sci 66: 725-735

19. NIEVA MORENO MI, ISLA MI, SAMPIETRO AR, VATTUONE MA (2000) Comparison of the free radical-scavenging activity of propolis from several regions of Argentina. J Ethnopharmacol 71: 109-114

20. PETRONE WF, ENGLISH DK, WONG K, MCCORD JM (1980) Free-radicals and inflammation: superoxide dependent activation of a neutrophil activating factor in plasma. Proc Natl Acad Sci USA 77: 1159-1163

21. RICARDO DA SILVA JM, DARMIN N, FERNÁNDEZ Y, MITJAVILA S (1991) Oxygen free radical scavenger capacity in aqueous models of different 
procyanidins from grape seeds. J Agric Food Chem 39: $1549-1552$

22. RICE-EVANS CA, MILLER NJ, PAGANGA G (1996) Structure-antioxidant activity relationships of flavonoids and phenolic acids. Free Radical Biol Med 20: $933-956$

23. ROBAK J, GRYGLEWSKI RJ (1996) Bioactivity of flavonoids. Polish J Ethnopharmacol 48: 555-564

24. SANDOVAL M, CHARBONNET RM, OKUHAMA NN, ROBERTS J, KRENOVA Z, TRENTACOSTI AM, MILLER MJ (2000) Cat's claw inhibits TNFalpha production and scavenges free radicals: Role in cytoprotection. Free Radical Biol Med 29: 71-78

25. SATO M, RAMARATHNAM N, SUZUKI Y, OHKUBO T, TAKEUCHI M, OCHI H (1996) Varietal differences in the phenolic content and superoxide radical scavenging potential of wines from different sources. J Agric Food Chem 44: 37-41
26. SMITH MA, PERRY G, SAYRE LM, ANDERSON VE, BEAL MF, KOWALL N (1996) Oxidative damage in Alzheimer's. Nature 382: 120-121

27. VALENZUELA A, SANHUEZA J, NIETO S (2003) Cholesterol oxidation: Health hazard and the role of antioxidants in prevention. Biol Res 36: 291-302

28. VISIOLI F, KEAREY JF, HALLIWELL B (2000) Antioxidants and cardiovascular diseases: panaceas or tonics for tired sheep. Cardiovasc Res 47: 409

29. YEN G-C, HSIEH C-L (1998) Antioxidant activity of extracts from Du-zhong (Eucommia ulmoides) toward various lipid peroxidation models in vitro. J Agric Food Chem 46: 3952-3957

30. YOKOZAWA T, CHEN CP, DONG E, TANAKA T, NONAKA GI, NISHIOKA I (1998) Study on the inhibitory effect of tannins and flavonoids against the 1,1-diphenyl-2-picrylhydrazyl radicals. Biochem Pharmacol 56: 213-222 